\title{
Detection and partial molecular characterization of Grapevine fleck virus, Grapevine virus $D$, Grapevine leafroll-associated virus -5 and -6 infecting grapevines in Brazil
}

\author{
Detecção e caracterização molecular parcial de Grapevine fleck virus, Grapevine virus D, Grapevine \\ leafroll-associated virus -5 e -6 que infectam videiras no Brasil
}

\author{
Thor Vinícius Martins Fajardo ${ }^{\mathrm{I}^{*}}$ Marcelo Eiras $^{\mathrm{II}}$ Osmar Nickel $^{\mathrm{I}}$ Carla Rosa Dubiela ${ }^{\mathrm{III}}$ \\ Eliezer Rodrigues de Souto ${ }^{\text {III }}$
}

\section{- NOTE -}

\section{ABSTRACT}

Grapevine fleck, rugose wood and leafroll are three grapevine viral diseases whose causal agents (or associated viruses) respectively are Grapevine fleck virus $(G F k V)$, Grapevine virus $D(G V D)$ and Grapevine leafroll-associated virus 5 and 6 (GLRaV-5 and -6). The objective of this work was to perform a partial molecular characterization of local isolates of these four viral species that infect grapevines. The nucleotide and deduced amino acid sequences of complete genes of the coat protein (CP) (of GFkV), the CP and the RNA binding protein (of GVD), the CP and the partial hHSP70 gene (of GLRaV-5) and the partial hHSP70 gene (of GLRaV-6) were aligned and compared in silico with other isolates. These data extend the available information about Brazilian isolates of GFkV, GLRaV-5 and -6, and reports for the first time the GVD occurrence in Brazil.

Key words: diagnosis, sequencing, Maculavirus, Vitivirus, Ampelovirus, Vitis.

\section{RESUMO}

Mancha das nervuras, lenho rugoso e enrolamento das folhas são três doenças virais da videira, cujos agentes causais (ou vírus associados) são o Grapevine fleck virus (GFkV), o Grapevine virus D (GVD) e os Grapevine leafroll-associated virus 5 e $6(G L R a V-5$ e -6), respectivamente. O objetivo deste trabalho foi realizar a caracterização molecular parcial de isolados locais dessas quatro espécies virais que infectam videira. As sequências de nucleotídeos e de aminoácidos deduzidos dos genes completos da proteína capsidial (CP) (do $G F k V)$, da CP e da RNA binding protein (do GVD), da CP do GLRaV-5 e parte do gene codificador da hHSP70 do GLRaV5 e -6 foram alinhadas e comparadas in silico com sequências de outros isolados. Os dados obtidos expandem a informação existente sobre isolados brasileiros de GFkV, GLRaV-5 e - $6 e$ relatam pela primeira vez a ocorrência do GVD no Brasil.

Palavras-chave: diagnose, sequenciamento, Maculavirus, Vitivirus, Ampelovirus, Vitis.

At least fifty-eight virus species are recognized to infect grapevine (Vitis spp.) (MARTELLI, 2009). Grapevine fleck is a graft-transmissible disease of grapevine, caused by Grapevine fleck virus (GFkV), a phloem-limited and non-mechanically transmissible virus. GFkV possesses isometric particles ca. $30 \mathrm{~nm}$ in diameter and is the type member of the genus Maculavirus in the family Tymoviridae (MARTELLI, 2009). The viral genome is a positive-sense, singlestranded RNA with a genome size of 7,564 nucleotides (nt). GFkV causes latent infections in $\boldsymbol{V}$. vinifera cultivars, but induces specific foliar symptoms in the indicator host $\boldsymbol{V}$. rupestris (SABANADZOVIC et al., 2001). The complete nucleotide (nt) sequence of the GFkV (Italian isolate) was obtained by SABANADZOVIC et al. (2001). Posteriorly, FAJARDO et al. (2004) performed a partial characterization of the viral replicase gene of GFkV isolate from Brazil.

The rugose wood (RW) complex affects grapevines woody cylinder causing pitting and/or grooving in the region under the plant bark. Most rootstock/scion combinations express wood symptoms

'Embrapa Uva e Vinho, 95700-000, Bento Gonçalves, RS, Brasil. E-mail: thor@cnpuv.embrapa.br. *Autor para correspondência. IIInstituto Biológico de São Paulo, São Paulo, SP, Brasil.

IIIDepartamento de Agronomia, Universidade Estadual de Maringá (UEM), Maringá, PR, Brasil. 
in the field. Nowadays the incidence of this complex is recognized to have a strong economical impact worldwide on the grape industry (ROSA et al., 2011). Viruses associated with the RW complex are Grapevine virus A (GVA), Grapevine virus B (GVB) and Grapevine rupestris stem pitting-associated virus (GRSPaV) (DU-PREEZ et al., 2011). Another virus, Grapevine virus D (GVD) was detected in grapevine showing corky rugose wood symptoms, but its role in the RW complex is still unclear (ABOU-GHANEMetal., 1997). Taxonomically, GVA, GVB, and GVD belong to genus Vitivirus and GRSPaV to Foveavirus, both in the family Betaflexiviridae. The viruses associated with RW are usually transmitted in the vineyards via grafting and propagation of infected material (DU-PREEZ et al., 2011). GVA, GVB and GRSPaV have been reported in Brazil previously (LIMA, 2009). GVD is the less studied virus in the RW complex and few GVD sequences are available in databases. ROSA et al. (2011) showed that GVD induced severe growth reduction in cv. 'Freedom' rootstock with no symptoms on the woody cylinder of the plants.

Grapevine leafroll-associated viruses (GLRaVs) are a group of viruses that collectively or individually cause leafroll disease in grapevine. To date, eleven different viruses are associated with the grapevine leafroll disease. The disease is of economical importance and limits the production of grapes throughout the world. $\boldsymbol{V}$. vinifera foliar symptoms are a downward curling of the fully expanding leaves and a yellowing (in white cultivars) or reddening (in red cvs.) that intensifies at the end of the growing season. Berries tend to mature more slowly and irregularly resulting in a lower yield and reduced total soluble sugars, decreasing juice quality for wine and fruit juices (THOMPSON et al., 2012). The family Closteroviridae contains all GLRaVs, including GLRaV-5 (Ampelovirus) and -6 (tentative member in the genus Ampelovirus) (ABOU GHANEM-SABANADZOVIC et al., 2012). Recently, the complete genomes of GLRaV-5 (THOMPSON et al., 2012) and GLRaV-6 (ABOU GHANEM-SABANADZOVIC et al., 2012) were sequenced, revealing 13,384 and $13,807 \mathrm{nt}$ long, respectively. In Brazil, leafroll is one of the most important viral diseases of grapevine. So far, GLRaV-5 and -6 were serologically detected in leafroll diseased grapevines in Brazil (KUNIYUKI et al., 2003; KUNIYUKI et al., 2008). The objective of this work was to perform the partial molecular characterization of Brazilian isolates of GFkV, GVD, GLRaV-5 and -6.

Results presented were obtained from samples of cultivars commercially introduced in Brazil, of which a collection was maintained by Embrapa Uva $e$ Vinho in a screenhouse. Grapevines selected for virus isolation were from the cv. 'Rupestris' du Lot budinoculated with cv. 'Benefuji' exhibiting mild clearing in the minor veins of leaves. The cvs. 'Dolcetto' and 'Garganega' exhibited, respectively, reddening or yellowing of leaves, with the main veins remaining green, as well as curling down of leaf edges and coriaceous leaves. The cv. 'Cardinal' exhibited coriaceous and dark red spotted leaves. These symptoms could not be associated with a single virus, since these plants could be mixed infected by at least one more virus.

Total RNA extractions were performed using adsorption of nucleic acids on silica particles (DUBIELA, 2012). DNA fragments of GFkV, GVD, GLRaV-5 and -6 were amplified by RT-PCR using primer pairs listed in the table 1. The RT-PCR conditions were as reported previously (FAJARDO et al., 2004). Cloning and sequencing of the DNA amplified fragments were performed as described by DUBIELA (2012). The amplified sequences were aligned using the software ClustalX 1.8. Comparisons with other viral sequences available in the GenBank were performed using the BLASTn and BLASTp program (http:// www.ncbi.nlm.nih.gov). The molecular weight (MW) of the four viral proteins (three CPs and one RNA binding protein) were calculated using the software EXPASy (http://web.expasy.org/compute_pi/).

Until the present date, the number of available nucleotide sequences of these viruses is restricted to 3 for GVD, 4 for GLRaV-6, 23 for GFkV and 43 for GLRaV-5, thus additional sequence information about other isolates of these virus species is highly desirable. A DNA fragment of 719bp (base pairs) was successfully amplified by RT-PCR from isolate BF containing the complete nt sequence of the $\mathrm{CP}$ gene (ORF, Open reading frame) of GFkV, with $693 \mathrm{nt}$ and 230 deduced amino acids (daa) (Table 1 ), which showed the highest identities of nt and daa with the MT48 (SABANADZOVIC et al., 2001) and the $\mathrm{Cl}-1155$ isolates from Italy and Chile, respectively (Table 1), the only available at GenBank that allowed full alignment of the $\mathrm{CP}$ gene with $\mathrm{BF}$ isolate. The multiple alignment of the $\mathrm{CP}$ sequence of isolate $\mathrm{BF}$ with $\mathrm{GFkV}$ sequences from GenBank (MT48 and Cl-1155 isolates) revealed only two amino acid divergences (data not shown), suggesting there is a low variability among the analyzed GFkV isolates. The calculated MW of the GFkV BF isolate $\mathrm{CP}$ of $24.31 \mathrm{kDa}$ was similar to that reported by SABANADZOVIC et al. (2001).

The amplified GVD DNA fragment of 852bp contains two complete gene sequences (ORFs) from two GVD isolates named Dolc and Garg (Table 1): the CP gene with 486nt and 161daa (ORF4) and the RNA 
Table 1 - Sequences of primers tested in the RT-PCR detection and pairwise percent identities of nucleotide and deduced amino acid sequences among Brazilian and foreign grapevine virus isolates.

\begin{tabular}{|c|c|c|c|c|c|c|}
\hline $\begin{array}{l}\text { Virus } \\
\text { (isolate) }\end{array}$ & Primer sequence $\left(5^{\prime}-3^{\prime}\right)$ & $\begin{array}{l}\text { Brazilian GenBank } \\
\text { nucleotide accession }\end{array}$ & $\begin{array}{l}\text { Foreign isolate } \\
\quad \text { / Origin }\end{array}$ & $\begin{array}{l}\% \text { nucleotide } \\
\text { identity }\end{array}$ & $\begin{array}{l}\% \text { deduced } \\
\text { amino acid } \\
\text { identity }\end{array}$ & $\begin{array}{c}\text { Foreign } \\
\text { GenBank } \\
\text { nucleotide } \\
\text { accession }\end{array}$ \\
\hline \multirow{2}{*}{$\begin{array}{l}\text { GFkV } \\
\text { (BF) }\end{array}$} & $\begin{array}{l}\text { CCCTCTCCGCCTCG } \\
\text { TCTG (v) }\end{array}$ & \multirow[t]{2}{*}{ JN022610 } & MT48, Italy & $\begin{array}{l}96,1 \\
(\mathrm{CP})\end{array}$ & $\begin{array}{l}98,7 \\
(\mathrm{CP})\end{array}$ & NC_003347 \\
\hline & $\begin{array}{l}\text { GCCTCGGTTCATG } \\
\text { ACGAG }(\mathrm{c})\end{array}$ & & $\begin{array}{l}\text { Cl-1155, } \\
\text { Chile }\end{array}$ & $\begin{array}{l}93,9 \\
(\mathrm{CP})\end{array}$ & $\begin{array}{l}98,7 \\
(\mathrm{CP})\end{array}$ & HQ688989 \\
\hline \multirow{2}{*}{$\begin{array}{l}\text { GVD } \\
\text { (Dolc and Garg) }\end{array}$} & $\begin{array}{l}\text { GACGCAGGGATGT } \\
\text { ACCTTAGGACG (v) }\end{array}$ & JQ031715 (Dolc) & Italy & $\begin{array}{l}89,2 \\
(\mathrm{CP})\end{array}$ & $\begin{array}{l}95,0 \\
(\mathrm{CP})\end{array}$ & Y07764 \\
\hline & $\begin{array}{l}\text { CCTCTACTTATGG } \\
\text { AAATTGCGCTC (c) }\end{array}$ & JQ031716 (Garg) & Italy & $\begin{array}{c}93,8 \\
\text { (RNA-BP) }\end{array}$ & $\begin{array}{c}92,3 \\
\text { (RNA-BP) }\end{array}$ & Y07764 \\
\hline \multirow{2}{*}{$\begin{array}{l}\text { GLRaV-5 } \\
\text { (Card5) }\end{array}$} & $\begin{array}{l}\text { ATGTCTGGATCAG } \\
\text { TGCAGGACG (v) }\end{array}$ & \multirow[t]{2}{*}{ JQ821315 } & $\begin{array}{l}\text { Colg. A2, } \\
\text { Argentina }\end{array}$ & $\begin{array}{l}98,1 \\
(\mathrm{CP})\end{array}$ & $\begin{array}{l}98,1 \\
(\mathrm{CP})\end{array}$ & HQ828110 \\
\hline & $\begin{array}{l}\text { TCACCTCCTGTTAC } \\
\text { CCAAGAAG (c) }\end{array}$ & & Y217, France & $\begin{array}{l}95,0 \\
(\mathrm{CP})\end{array}$ & $\begin{array}{l}96,3 \\
(\mathrm{CP})\end{array}$ & NC_016081 \\
\hline \multirow{2}{*}{$\begin{array}{l}\text { GLRaV-5 } \\
\text { (Card5) }\end{array}$} & $\begin{array}{l}\text { AACACTCTGCTTTT } \\
\text { CTGCTGGC (v) }\end{array}$ & \multirow[t]{2}{*}{ JQ821314 } & Y217, France & $\begin{array}{c}96,0 \\
\text { (hHSP70) }\end{array}$ & $\begin{array}{c}100,0 \\
(\mathrm{hHSP70})\end{array}$ & NC_016081 \\
\hline & $\begin{array}{l}\text { RTCIAAIGTICCICCI } \\
\text { CCRAA (c) }\end{array}$ & & USA & $\begin{array}{c}95,2 \\
\text { (hHSP70) }\end{array}$ & $\begin{array}{c}100,0 \\
(\mathrm{hHSP70})\end{array}$ & AF233934 \\
\hline \multirow{2}{*}{$\begin{array}{l}\text { GLRaV-6 } \\
\text { (Card) }\end{array}$} & $\begin{array}{l}\text { GGITTIGAITTYGGI } \\
\text { ACIAC (v) }\end{array}$ & \multirow[t]{2}{*}{ JQ290111 } & \multirow[t]{2}{*}{ Estellat, USA } & $\begin{array}{c}97,4 \\
\text { (hHSP70) }\end{array}$ & $\begin{array}{c}97,0 \\
\text { (hHSP70) }\end{array}$ & \multirow[t]{2}{*}{ NC_016417 } \\
\hline & $\begin{array}{l}\text { RTCIAAIGTICCICCI } \\
\text { CCRAA (c) }\end{array}$ & & & & & \\
\hline
\end{tabular}

- GFkV, GVD and GLRaV-5 (CP) primers designed in this work, GLRaV-5 (hHSP70) and GLRaV-6 primers cited by DUBIELA et al. (2012); (v) forward, (c) reverse; I (inosine); CP (coat protein), RNA-BP (RNA binding protein) and hHSP70 (homologous heat shock protein 70); the comparisons include only foreign isolates whose available gene sequences were complete.

binding protein (RNA-BP) gene with 276nt and 91daa (ORF5). Since the RNA-BP gene, encoded by ORF5 of Vitivirus, has gene silencing suppressor functions and of pathogenicity determinant in GVA(DU-PREEZ et al., 2011), it may be assumed to have the similar functions in GVD. The calculated MW of the CP $(17.65 \mathrm{kDa})$ and RNA-BP $(10.34 \mathrm{kDa})$ of isolate Dolc of GVD were very similar to a previous report (DU-PREEZ et al., 2011).

The nt and daa sequences of Dolc and Garg GVD isolates showed high identity (over ca. 90\%) with the Italian isolate (ABOU-GHANEM et al., 1997), the only GVD isolate completely sequenced for the $\mathrm{CP}$ and RNA-BP genes (Table 1). The high identity among the three GVD isolates (Dolc, Garg and Italian isolate) was confirmed by the multiple alignment of the daa sequences, considering both $\mathrm{CP}$ (eight divergences) and RNA-BP (7-8 divergences) of the sequenced genes (data not shown), suggesting a low variability among the analyzed GVD isolates.

Fragments of GLRaV-5, amplified from extracts of cv. 'Cardinal', contain the complete sequence of the CP gene with 798nt and 265daa and the partial hHSP70 gene with 565nt and 188daa (Table 1). The calculated MW of the Card5 isolate CP of $28.95 \mathrm{kDa}$ was similar to a previous report of THOMPSON et al. (2012). The nt and daa sequences of Card5 CP and 
partial hHSP70 genes showed high identities (more than 96\%) with the Argentinean (Colgadera A2) and French (Y217) isolates, respectively (Table 1). In the multiple alignment of daa sequences of the Card5 isolate and the Argentinean (CP) or French (hHSP70) GLRaV5 isolates, there were five divergences in the $\mathrm{CP}$ coding region, whereas no divergences were found for the hHSP70 protein partial coding region (data not shown), suggesting limited variability among the GLRaV-5 analized isolates.

The GLRaV-6 Card isolate from cv. 'Cardinal' was amplified by RT-PCR resulting in a DNA fragment of expected size. This fragment contains the partial sequence of the hHSP70 gene with 591nt and 197daa (Table 1). The Card isolate sequences showed the highest nt and daa identities with the GLRaV-6 Estellat isolate (Table 1), characterized by ABOU GHANEMSABANADZOVIC et al. (2012). In the alignment of daa sequences, there were six divergences between these two isolates (data not shown), indicating restricted variability among the GLRaV-6 analized isolates. Viruses associated with leafroll disease are frequently found in mixed infection, therefore extended informations about nucleotide sequences of more isolates is relevant to overcome the inherent difficulties of molecular detection and characterization of these viruses.

This work constitutes the first characterization of the complete CP gene of a GFkV isolate from Brazil, the first report of GVD sampled in grapevines in Brazil and the first molecular characterizations of the GLRaV-5 and GLRaV-6 isolates from grapevines in Brazil. These results expand our knowledge on the variability of these viruses. These results provide relevant information for the development of improved detection and control strategies in the frame of programs for production of healthy grapevine material.

\section{REFERENCES}

ABOU GHANEM-SABANADZOVIC, N. et al. Genome organization, serology and phylogeny of Grapevine leafrollassociated viruses 4 and 6: taxonomic implications. Virus Research, v.163, p.120-128, 2012. Available from: <http:// dx.doi.org/10.1016/j.virusres.2011.09.001>. Accessed: sep. 03, 2012. doi: 10.1016/j.virusres.2011.09.001.

ABOU-GHANEM, N. et al. Properties of Grapevine virus D, a novel putative trichovirus. Journal of Plant Pathology, v.78, p.15-25, 1997.
DUBIELA, C.R. Detecção por RT-PCR em tempo real (Taqman) e caracterização molecular parcial de vírus que infectam a videira. 2012. 127f. Dissertação (Mestrado em Genética e Melhoramento) - Universidade Estadual de Maringá, PR.

DU-PREEZ, J. et al. The grapevine infecting vitiviruses, with particular reference to Grapevine virus A. Archives of Virology, v.156, p.1495-1503, 2011. Available from: <http:/ /dx.doi.org/10.1007/s00705-011-1071-3>. Accessed: sep. 03, 2012. doi: 10.1007/s00705-011-1071-3.

FAJARDO, T.V.M. et al. Detecção e caracterização molecular parcial do Grapevine fleck virus em videiras. Fitopatologia Brasileira, v.29, p.460, 2004. Available from: <http:// dx.doi.org/10.1590/S0100-41582004000400020>. Accessed: sep. 03, 2012. doi: 10.1590/S0100-41582004000400020.

KUNIYUKI, H. et al. Ocorrência do Grapevine leafrollassociated virus 6 em vinhedos do Brasil. Summa Phytopathologica, v.29, p.288-289, 2003.

KUNIYUKI, H. et al. Detecção do Grapevine leafrollassociated virus 5 no Estado de São Paulo. Summa Phytopathologica, v.34, p.366-367, 2008. Available from: $<$ http://dx.doi.org.ez103.periodicos.capes.gov.br/10.1590/ S0100-54052008000400014>. Accessed: sep. 03, 2012. doi: 10.1590/S0100-54052008000400014.

LIMA, M.F. Detecção e controle de viroses em videira. Petrolina: Embrapa Semiárido, 2009. 9p. Disponível em: <http://www.cpatsa.embrapa.br:8080/public_eletronica/ downloads/CTE90.pdf>. Acesso em: 02 ago. 2012.

MARTELLI, G.P. Grapevine virology highlights 2006-09. In: MEETING OF INTERNATIONAL COUNCIL OF VIRUSES AND VIRUS DISEASES OF GRAPEVINE, 16., 2009, Dijon, France. Extended abstracts... Dijon:ICVG, 2009. p.15-23.

ROSA, C. et al. Symptomatology and effects of viruses associated with rugose wood complex on the growth of four different rootstocks. American Journal of Enology and Viticulture, v.62, p.207-213, 2011. Available from: <http:// dx.doi.org/10.5344/ajev.2011.10104>. Accessed: sep. 03, 2012. doi: 10.5344/ajev.2011.10104.

SABANADZOVIC, $\mathrm{S}$. et al. Complete nucleotide sequence and genome organization of Grapevine fleck virus. Journal of General Virology, v.82, p.2009-2015, 2001. Available from: <http://vir.sgmjournals.org.ez103.periodicos.capes.gov.br/ content/82/8/2009.full.pdf+html>. Accessed: sep. 03, 2012.

THOMPSON, J.R. et al. Genomic analysis of Grapevine leafroll associated virus 5 and related viruses. Virus Research, v.163, p.19-27, 2012. Available from: <http://dx.doi.org/10.1016/ j.virusres.2011.08.006>. Accessed: sep. 03, 2012. doi: 10.1016/ j.virusres.2011.08.006. 